\title{
Effect of Solution Focused Group Counseling for High School Students in Order to Struggle with School Burnout
}

\author{
Bünyamin Ateş \\ Correspondence: Bünyamin Ateş, PhD, Faculty of Education, Erzincan University, Erzincan, 24000, Turkey
}

Received: December 17, 2015 Accepted: December 31, 2015 Online Published: January 12, 2016

doi:10.11114/jets.v4i4.1254

URL: http://dx.doi.org/10.11114/jets.v4i4.1254

\begin{abstract}
In this research, the effect of solution focused group counseling upon high school students' struggling with school burnout was analyzed. The research was an experimental study in which a pre-test post -test control group random design was used, depending upon the real experimental model. The study group included 30 students that volunteered from among students studying at a high school in central Erzincan Province in the 2014-2015 academic year. School Burnout Scale (Seçer, Halmatov, Veyis and Ateş, 2013) and Personal Information Form were used in the study as data collection tools. Independent Samples t-test and One Factor ANCOVA were performed to analyze the obtained data. At the end of the research, it was determined that solution focused group counseling was effective upon high school students' struggling with school burnout, and this effect actualized as independent from the variable of gender.
\end{abstract}

Keywords: solution focused psychological counseling, school, school burnout, high school, students

\section{Introduction}

When people work or achieve something in any field, they need to know that their achievement is significant and what they achieve is beneficial. When people do not have these feelings, they become disappointed and dissatisfied with their work. And this creates burnout in individuals. The concept of burnout has been the focus of researchers since the beginning of 1970s. Freudenberger (1974), defined burnout as an individual's failure, fatigue, and exhaustion depending upon over use of energy, power and sources. Maslach, defined burnout as individuals in service sectors' with a profession serving to people experiencing emotional burnout, their indifference in fulfilling their work, their depersonalization, and decrease in personal success and competence perceptions (Maslach \& Jackson, 1981; Maslach \& Goldberg, 1998; Maslach, Schaufeli \& Leiter, 2001). In this sense, burnout, in general, is characterized as three-dimensional. It includes the emotional burnout associated with decrease and loss in emotional support sources, desensitization associated with cynic, indifferent and negative attitude toward work and fulfilling the work, and personal failure in which incompetence and failure feelings were dominant. The emotional dimension of burnout represents basic stress components, the dimension of indifference represents the components of interpersonal relations, and the dimension of personal failure represents the components of self-evaluation. In previous research, "professional burnout" was mostly emphasized, and lack of positive feedback, control deficiency, adequately unclear roles, stress, lack of social support, unreal expectations related to work, work overload, interpersonal conflict and disagreements, etc. were especially listed as the risk factors increasing the professional burnout (Freudenberger, 1974; Küçüksüleymanoğlu \& Eğilmez, 2013; Maslach \& Jackson, 1981: Maslach \& Jackson, 1984; Maslach \& Goldberg, 1998; Maslach, Schaufeli \& Leiter, 2001).

Burnout syndrome is not a situation that immediately occurs; in contrast, it has gradually developing symptoms. Ignorance of burnout symptoms causes the syndrome to progress and becomes impossible to cope with. Burnout has emotional indicators (fear, hopelessness, desperation, uneasiness, anger, emotional deprivation, anxiety, worthlessness, disappointment, professional dissatisfaction, timidity, etc.), physical indicators (low energy, physical tiredness, exhaustion, psychosomatic complaints, impatient and aggressive behaviors, assuming an cynic attitude, etc.) and cognitive indicators (assuming a negative attitude against the self, profession, and life) (Ardıc \& Polatcı,2008; Freudenberger,1974; Maslach \& Jackson, 1981; Maslach \& Goldberg,1998; Schaufeli \& Maslach,1993). In studies about burnout, it was noticed that burnout was a problem related to the variables such as social support perception (Gündüz, 2005; Kim, Lee \& Kim, 2009; Kutsal \& Bilge, 2012), perfectionism and stress (Çam, Deniz \& Kurnaz, 2014; Millicent \& Joanne, 1999), professional competence (Çelikkaleli, 2011), the perception of self-efficacy (Karahan \& Balat, 2011; İkiz, 2010), physical exhaustion, sleeplessness, use of alcohol and drugs, marriage and familial problems 
(Maslach \& Jackson, 1981) and level of life satisfaction (Ünal, Karlıdağ \& Yoloğlu, 2001).

Burnout indicates an inversion among the things people do and have to do, whatever they carry on, and represents the erosion in values, honor, prestige and spirits of individuals. The fact of burnout captures the whole life of individuals. It affects all work performance of individuals as well as their social and private relationships (Gündüz, Çapri \& Gökçakan, 2012; İkiz, 2010).

Burnout is mostly encountered in individuals in professional groups that are required to establish relationships with people such as health, education, and social services. Previous studies, therefore, mostly emphasized upon these professional groups, in general (Bakker \& Schaufeli, 2006; Günüșen \& Üstün, 2010; Horn, Schaufeli \& Enzmann, 1999; Küçüksüleymanoğlu, 2007; Maslach \& Goldberg, 1998; Maslach, Schaufeli \& Leiter, 2001; Millicent \& Joanne, 1999; Otacıŏglu, 2008; Schaufeli \& Maslach, 1993; Sayıl, Haran, Ölmez \& Özgüven, 1997; Vahey, Aiken, Sloane, Clarke, \& Vargas, 2004).

It has been noticed in time that burnout is not only a problem that affects the employees of specific professions, but also the students. When the lives of students are analyzed in psychological terms, although they are neither employees nor employers, it is possible to accept their academic-content duties and responsibilities as a work because of the continuance of these. Students have to fulfill several duties and responsibilities related to their academic life. However, these duties and responsibilities can lead them into burnout after a while. The stress students experience during the educational process, course overload, and other psychological factors (stress, depression, etc.) can cause them to experience school burnout. School burnout is defined as students' feeling incompetence and developing cynical and indifferent attitudes towards the school. School burnout that is related to emotional behavioral problems such as depression and stress can cause decreasing in interest and motivation towards courses, school absence, and school drop-out. Furthermore, school burnout can reveal indifference, emotional burnout, and personal failure as indicators of burnout affecting academic success, and self-efficacy perceptions of students negatively. This causes decrease in interest and motivation towards school and courses and negativity in students' fulfilling their duties and responsibilities related to school (Aypay \& Eryılmaz, 2011; Bilge, Dost \& Çetin, 2014; Breso, Salanova \& Schaufeli, 2007; Çam, Deniz \& Kurnaz, 2014; Küçüksüleymanoğlu \& Eğilmez, 2013; Meier \& Schmeck, 1985; Seçer \& Gençdoğan, 2012; Yang \& Farn, 2005).

In analyses, it was determined that school burnout was related to be associated with several variables. Some of these variables included academic success (Balkıs, Duru, Buluş \& Duru, 2011; Çapulcuoğlu \& Gündüz, 2013), depression (Gan, Yang, Zhou \& Zhang, 2007; Salmela-Aro, Savolainen \& Holopainen, 2009), subjective well-being level (Aypay \& Eryllmaz, 2011), stress, perfectionism, self-efficacy and social support perception (Çam, Deniz \& Kurnaz,2014; Yang \& Farn, 2005), self-reliance and sense of self (Meier \& Schmeck, 1985).

In Turkey, having a good education generally depends upon success in normal examinations, as well as the central examination performed during the educational process. And this involves students in a serious competition for all grades in education. Students can suffer from mental erosion as result of the success demand and pressure they are exposed to and envolve into the burnout process easily (Aypay \& Eryılmaz, 2011; Gündüz; Çapri \& Gökçakan, 2012). In this sense, the importance of struggling with school burnout that has a negative effect upon both academic success and mental well-being of students becomes prominent. When the literature was reviewed, it was noticed in general that the variable of burnout was discussed with different variables, and various suggestions were offered in order to struggle with burnout. However, it was also remarkable that there were a limited number of studies carried out, depending upon a specific counseling approach for struggling with school burnout. Within this framework, it was considered that experimenting with a solution focused psychological counseling approach would be significant as a different implementation so as to struggle with students' school burnout.

Solution focused brief psychological counseling is an approach developed in the USA in the last quarter of the $20^{\text {th }}$ century. The leading pioneers of the approach are possible to be listed as Steve de Shazer, Insoo Kim Berg, and Bill O'Hanlon. General properties of this approach include focusing on solutions instead of problems using a solution focused language structure instead of a problem focused language structure, focusing on now and future instead of the past, and focusing on serviceable actions, little changes, strengths and sources in counselee, etc. Solution focused brief psychological counseling is a fairly optimist approach in case of the counselee's change. In this approach, the number of sessions can generally vary between four and six. The leading techniques, including pre-session change technique, the formula first session task, the miracle question, scaling questions, exception situations and crystal ball technique (De Shazer, 1985; De Shazer \& Berg, 1997; De Jong \& Berg, 1998; Doğan, 1999; Gladding, 2013; Lethem, 2002; Murdock, 2012; Sklare, 2013). In reviewing the literature, it was noticed that solution focused counseling approach was efficient upon struggling with different problems that were possible encountered in schools (Ateş, 2014; Brown, Powell \& Clark, 2012; Franklin, Moore \& Hopson, 2008; Newsome, 2005; Tuna, 2012; Vallaire, Hicks \& Growe, 2011). In this study, it 
was determined to analyze the effect of solution focused group counseling upon struggling with school burnout of the high school students. In accordance with this purpose, the answer to the question, "Is solution focused group counseling efficient upon struggling with school burnout of high school students?" was attempted to be determined in this study.

\section{Method}

\subsection{Research Model}

This research was an experimental study in which pre-test post-test control-group random design focused upon using the real experimental model. The experimental design related to the performed study is presented in Table 1.

Table 1. Experimental Design of the Study

\begin{tabular}{lllll}
\hline Group & N & Pre-test Implementation & Experimental Process & Post-test Implementation \\
\hline $\begin{array}{l}\text { Experimental } \\
\text { Group }\end{array}$ & 15 & School Burnout Scale & $\begin{array}{l}\text { Solution focused } \\
\text { counseling for } 90 \text { min } \\
\text { once a week }\end{array}$ & School Burnout Scale \\
Control Group & 15 & School Burnout Scale & $\begin{array}{l}\text { No implementation was } \\
\text { performed }\end{array}$ & School Burnout Scale \\
\hline
\end{tabular}

In this research, the independent variable was group counseling carried out depending upon solution focused approach. And the dependent variable was high school students' level of school burnout.

\subsection{Study Group}

The study group included 30 volunteered students volunteered among those studying at a high school in central Erzincan Province in the 2014-2015 academic year. The descriptive information related to the study group is presented in Table 2 and Table 3.

Table 2. Descriptive Statistics of the Groups in Terms of Gender

\begin{tabular}{lccc}
\hline Gender & Female N & Male N & Total N \\
\hline Experimental Group & 8 & 7 & 15 \\
Control Group & 6 & 9 & 15 \\
Total & 14 & 16 & 30 \\
\hline
\end{tabular}

Table 3. Descriptive Statistics of the Groups in Terms of Age

\subsection{Data Collection Tools}

\begin{tabular}{|c|c|c|c|}
\hline & & \multicolumn{2}{|c|}{ Age } \\
\hline & & $\mathrm{N}$ & $\bar{X}$ \\
\hline \multirow{3}{*}{ Group } & Experimental & 15 & 15.87 \\
\hline & Control & 15 & 15,73 \\
\hline & Total & 30 & 15.80 \\
\hline
\end{tabular}

\subsubsection{School Burnout Scale}

The scale was developed by Salmela-Aro, Kiuru, Leskinen and Nurmi (2009) in order to determine school burnout levels of students studying at elementary and secondary educational grades. The scale was adapted into Turkish culture by Seçer, Halmatov, Veyis and Ateş (2013). The scale is a five-point Likert Scale measurement instrument including nine items in its original form. Reliability and validity studies of the scale were carried out through the data collected from 570 students studying at elementary and secondary education schools. For the construct validity, exploratory and confirmatory factor analyses were performed. The results of exploratory factor analysis revealed that the scale explained totally 66,858 percent variance in three dimensions. Model coherence of this three dimensional structure was tested through confirmatory factor analysis, and fit indexes were determined to be at a good level $(\mathrm{RMSEA}=.042, \mathrm{RMR}=.013$, $\mathrm{NFI}=.90, \mathrm{CFI}=.96$, IFI=.97, RFI=.92, AGFI=.90, GFI=.92). These sub-dimensions included emotional burnout, indifference and feeling of low personal success. As result of the scale's reliability analysis, internal consistency coefficient was found to be $a=.75$, and test re-test reliability was found to be $a=.80$. In accordance with the obtained data, it was concluded that school burnout scale was a measurement tool with validity and reliability. Within the scope of this study, test re-test reliability coefficient was determined to be 0.82 for all scale.

\subsubsection{Personal Information Form}

Within the scope of the research, personal information form was developed to obtain personal information of the students creating the research group of the study by the researcher.

\subsection{Data Analysis}

In this study, whether group data had a parametric value or not was analyzed through scatter graphic and Shapiro-Wilks normality test; and the groups were determined to have normal distribution. In this sense, Independent Samples T-test and One Factor ANCOVA were used in order to test the obtained data. Data analyses were performed on computer 
environment through SPSS programs. In the study, .05 level of significance was considered (Büyüköztürk, 2011; Can, 2013).

\subsection{Process}

In order to create the study group, appropriate course hours of the students were determined. Students were informed about the study in these course hours, and School Burnout Scale was performed on 178 student volunteers that participated into the study. Subsequently, scale scores of the students were listed from the highest to the lowest, and 30 volunteer students with high school burnout scores were determined. Then, these students were randomly distributed to experimental and control groups including of 15 each. To the students in the experimental groups, six-session solution focused group counseling sessions were developed and organized within the scope of the research in accordance with the basic philosophy, principles and techniques of solution focused group counseling were organized. The sessions were held for nearly 90 minutes once a week. For the students in the control group, normal educational activities were maintained to be carried out without any processes. After completing the planned group process, post-test (School Burnout Scale) was performed on both groups. At the end of the study, a 60-minute seminar related to school burnout was provided to the students in the control group in order to conform to the professional ethics.

\subsection{Program Development and Implementation Process}

Within the scope of this study, the research performed abroad and in Turkey related to school burnout and solution focused group psychological counseling were primarily reviewed; the framework of the program to be carried out was created. Then, pre-experimental sessions including four sessions were performed with eight students in order to determine practicability of the program. Depending upon performed pre-experimental studies, the deficiencies of the program were determined, and the program was accommodated into the study group. The implementation process of the program was shortly carried out as such:

$\underline{I}^{\text {st }}$ Session (Acquaintance)

In the first session, the purpose of the group was explained, group members introduced themselves to the group, group rules were created, general information on solution focused group counseling and school burnout was shared, group members were helped to express their purposes positively, pre-session positive changes were focused on, and the task of the first session was formulated.

\section{$2^{\text {nd }}$ Session (Change)}

In the second session, group members' expressed their purposes more clearly, and their noticing the solution and change were emphasized. In this session, "Miracle Question Technique" was performed.

\section{$\underline{3}^{\text {rd }}$ Session (Strengths and sources)}

In this session, group members' current sources, achievements and strengths upon struggling with school burnout was emphasized.

\section{$\underline{4^{\text {th }} \text { Session (Rare situations) }}$}

In the fourth session, group members' strengths and competences upon struggling with burnout was emphasized focusing on the moments they experience little or no burnout (exceptional moments technique) in accordance with the purpose of the previous session.

\section{$5^{\text {th }}$ Session (Prospective Questions)}

In this session, group members were asked to design their own situation in a future they desire when there is no problem, and these were shared.

\section{$\sigma^{\text {th }}$ Session (Finalization)}

In this session, group members were asked to evaluate the group process and group experiences related to themselves. During this study process, "scaling questions" were used for the group members to evaluate themselves and the counseling process.

\section{Findings}

In this study, Independent Samples T-test and One Factor ANCOVA was used for the analysis of data, and the obtained data is presented in Table 4.

Table 4. Independent Samples T-test Results Related to Pre-Test Scores of Experimental and Control Groups

\begin{tabular}{llllllc}
\hline School Burnout & $\mathrm{N}$ & $\bar{X}$ & $\mathrm{~S}$ & $\mathrm{df}$ & $\mathrm{t}$ & $\mathrm{p}$ \\
\hline Control Group & 15 & 37.60 & 2.32 & 28 & -.606 & .232 \\
Experimental & 15 & 38.20 & 3.05 & & & \\
Group & & & & & & \\
\hline
\end{tabular}


When Table 4 was analyzed, no significant difference was determined between School Burnout Scale scores performed as pre-test to the experimental and control groups $\left(\mathrm{t}_{28}=-.606, \mathrm{p}>.05\right)$. This finding proved that pre-process groups were equal to each other in terms of their school burnout scores.

After group equalities, it was analyzed whether curves of regression lines were equal or not as one of the conditions of ANCOVA, and whether group $\mathrm{x}$ gender common effect was significant or not upon the school burnout scores when the gender of variable that would create a possible effect upon variance homogeneity and group was controlled. Covariance (ANCOVA) analysis results related to the common effect of group and gender is presented in Table 5.

Table 5. Covariance (ANCOVA) Analysis Results Related to the Common Effect of Group and Gender

\begin{tabular}{llllll}
\hline Source of Variance & Sum of Squares & df & Mean Square & F & p \\
\hline Group & 126.63 & 1 & 126,63 & & \\
Gender & .167 & 1 & .167 & .262 & .613 \\
Group*Gender & 3.65 & 1 & 3.65 & & \\
Error & 363.07 & 26 & 13.96 & & \\
Total & 1318.96 & 29 & & & \\
\hline
\end{tabular}

When Table 5 was analyzed, it was noticed that group $\mathrm{x}$ gender common effect was significant upon school burnout scores of the groups $\left(\mathrm{F}_{1,26}=.262, \mathrm{p}>.05\right)$. This finding proved that curves of regression lines were equal. Moreover, it was also specified that the condition of variance homogeneity was provided as result of Levene's test ( $\mathrm{p}=.108, \mathrm{p}>.05)$.

After this analysis, it was tested whether there was a significant difference between corrected test scores related to school burnout scores of the groups and is presented in Table 6 .

Table 6. Descriptive Statistics of School Burnout Scores According to Groups

\begin{tabular}{llll}
\hline Group & $\mathrm{N}$ & Average & Corrected Average \\
\hline Control & 15 & 38.60 & 38,54 \\
Experimental & 15 & 27.33 & 27.29 \\
\hline
\end{tabular}

When Table 6 was analyzed, it was noticed that the experimental group had lower average value rather than the control group in terms of the groups according to corrected average scores. ANCOVA results performed to determine whether the difference observed between corrected average scores of the groups was significant or not were presented below in Table 7.

Table 7. Covariance (ANCOVA) Analysis Results

\begin{tabular}{lllllll}
\hline Source of Variance & Sum of Squares & df & Mean Square & F & p & $\eta^{2}$ \\
\hline Gender & .196 & 1 & .196 & .014 & .905 & .001 \\
Group & 931.41 & 1 & 931.41 & 68.57 & .000 & .717 \\
Error & 366.73 & 27 & 13.58 & & & \\
Total & 1318.96 & 29 & & & & \\
\hline
\end{tabular}

It was determined, as indicated in Table 7, at the end of this research in which the effect of solution focused group counseling upon high school students' struggling with school burnout that the difference between the experimental and control groups was significant $\left(\mathrm{F}_{1,27}=68.57, \mathrm{P}<.01, \eta^{2}=.717\right)$. this finding proved that the difference observed between corrected average scores of the students in experimental and control groups was significant, the program performed to the experimental group had a positive effect upon students' struggling with the school burnout, and this affect occurred independently from the variable of gender.

\section{Conclusion and Discussion}

In this study, it was remarkable for the groups to be equal in order to reveal the effect of the experimental process. So that the difference between post-test scores of the groups can be focused upon the effect of experimental process. In this research, whether there was a significant level of difference between the pre-test scores of the experimental and control groups or not was primarily considered, and no significant level of difference was observed between the pre-test scores of the experimental and control groups as result of performed analyses. This finding proved that the pre-process groups were equal to each other.

After determining that there were no significant level of difference between the pre-process group scores, and the groups had distributions close to each other, experimental process and data analyses were performed subsequently. As result of performed data analyses, it was specified that school burnout scores of the students in the experimental group decreased more significantly rather than the control group and pre-program situation. Furthermore, the variable of gender that was possible to affect the experimental process was kept under control through the covariance (ANCOVA) analysis. The change in the experimental group was supported through verbal feedback obtained from the students.

At the end of this research in which the effect of group psychological counseling upon high school students' struggling with school burnout was analyzed, it was possible to mention that solution focused group psychological counseling was 
efficient upon high school students' struggling with school burnout, and this effect occurred independent from the variable of gender.

It was noticed in the literature review upon the school burnout that various variables related to school burnout were emphasized. Some of these variables could be listed as academic success, level of subjective well-being, stress, perfectionism, self-efficacy, social support perception, self-reliance and sense of self (Aypay \& Eryllmaz, 2011; Balkıs, Duru, Buluş \& Duru,2011; Çam, Deniz \& Kurnaz,2014; Çapulcuoğlu \& Gündüz, 2013; Kiuru, Aunola, Nurmi, Leskinen \& Salmela-Aro, 2008; Meier \& Schmeck,1985: Meylan, Doudin, Curchod \& Stephan, 2011; Yang \& Farn, 2005). It was remarkable to determine the variables related to school burnout; however, the inadequacy of the studies carried out upon school burnout was also significant. In analyses upon this subject, different suggestions related to burnout were generally developed (Ardıç \& Polatcı, 2008; Awa, Plaumann \& Walter, 2010; Kravits, Mc Allister-Black, Grant \& Kirk, 2010; Lambie, 2006; Maslach \& Goldberg, 1998); however, it was also noticed that the studies carried out on the basis of psychological counseling were not adequately emphasized. Upon struggling with school burnout, the study carried out by İlbay (2014) was remarkable. In this study, the effect of solution focused group psychological counseling upon university students' burnout level was analyzed, and it was determined that solution focused group psychological counseling was efficient upon decreasing the burnout levels of university students, and this effect was also available during the follow-up studies. It was concluded that the result of this study and the one we carried out were similar. Both in the study carried out by İlbay (2014) and this study, it was noticed that solution focused group psychological counseling was an efficient and beneficial approach upon students' struggling with school/student burnout.

It was known that solution focused psychological counseling was a beneficial approach upon overcoming several problems encountered in school environment efficiently as well as school burnout (Brown, Powell \& Clark, 2012; Çitemel, 2014; Franklin, Moore \& Hopson, 2008; Newsome, 2005; Tuna, 2012). Solution focused psychological counseling was efficient upon overcoming the problems encountered in school environment because focusing on students' solutions, their strengths, achievements, positive changes, rare moments and sources was important and beneficial according to this approach. Moreover, it could also provide opportunities to focus on students' positive sides instead of their negative sides, and solutions instead of problems, and to obtain terminal results reaching solutions in a short time. To sum up, solution focused group counseling was possible to be mentioned as an approach efficient on struggling with several problems including school burnout, as well.

\section{Suggestions}

Within the scope of this study, these suggestions were offered: A similar study is possible to be carried out with different research groups. The content of the program developed within the scope of the research should be changed according to the need. Seminars, conferences, etc. should be provided upon increasing the awareness levels of educationalists, school directors, and parents upon school burnout within the scope of protective mental health. In accordance with the same purpose, different studies (seminars, training groups, programs, etc.) related to the students should be included. In this sense, determining the factors that cause school burnout in students and the precautions to be taken in terms of protective mental health are remarkable.

\section{References}

Ardıç, K., \& Polatcı, S. (2008). Tükenmişlik sendromu akademisyenler üzerinde bir uygulama (GOÜ Örneği). Gazi Üniversitesi İktisadi ve İdari Bilimler Fakültesi Dergisi, 10 (2), 1-28.

Ateş, B. (2014). Üniversite Öğrencilerinin Sosyal Fobi ile Başa Çıkmalarında Çözüm Odaklı Grupla Psikolojik Danışmanın Etkisinin Incelenmesi. Yayımlanmamış doktora tezi. Atatürk Üniversitesi Eğitim Bilimler Enstitüsü, Erzurum.

Awa,W. L., Plaumann, M., \& Walter, U. (2010). Burnout prevention: A review of intervention programs. Patient Education and Counseling, 78(1), 184-190. http://dx.doi.org/10.1016/j.pec.2009.04.008

Aypay, A., \& Eryılmaz, A. (2011). Lise öğrencilerinin öznel iyi oluşları ve okul tükenmişliği arasındaki ilişkiler. International Online Journal of Educational Sciences, 3(1), 181-199.

Balkıs, M., Duru, E., Buluş, M., \& Duru, S. (2011). Tükenmişliğin Öğretmen Adayları Arasındaki Yaygınlığı, Demografik Değişkenler ve Akademik Başarı ile İlişsisi. Pamukkale Üniversitesi Eğitim Fakültesi Dergisi, 29(1), 151-165.

Bilge, F., Dost, M. T., \& Çetin, B. (2014). Factors Affecting Burnout and School Engagement among High School Students: Study Habits, Self-Efficacy Beliefs, and Academic Success. Educational Sciences: Theory \& Practice, 14(5), 1721-1727.

Breso, E., Salanova, M., \& Schaufeli, W. B. (2007). In search of the "third dimension" of burnout: Efficacy or 
inefficacy?. Applied Psychology, 56(3), 460-478. http://dx.doi.org/10.1111/j.1464-0597.2007.00290.x

Brown, E. L., Powell, E., \& Clark, A. (2012). Working on what works: Working with teachers to improve classroom behaviour and relationships. Educational Psychology in Practice, 28(1), 19-30. http://dx.doi.org/10.1080/02667363.2011.639347

Büyüköztürk, Ş. (2011). Sosyal Bilimler İçin Veri Analizi El Kitabı. (15. Baskı). Ankara: Pegem Akademi Yayıncılık.

Çam, Z., Deniz, K. Z., \& Kurnaz, A. (2014). Okul Tükenmişliği: Algılanan Sosyal Destek, Mükemmeliyetçilik ve Stres Değişkenlerine Dayalı Bir Yapısal Eşitlik Modeli Sınaması. Eğitim ve Bilim, 39(173), 312-327.

Can, A. (2013). SPSS ile Bilimsel Araştırma Sürecinde Nicel Veri Analizi. Ankara: Pegem Akademi Yayıncılık.

Çapulcuoğlu, U., \& Gündüz, B. (2013). Lise öğrencilerinde tükenmişliğin cinsiyet, sınıf düzeyi, okul türü ve algılanan akademik başarı değişkenlerine göre incelenmesi. Trakya Üniversitesi Eğitim Fakültesi Dergisi, 3(1), 12-24.

Çelikkaleli, Ö. (2011). Yetişkin eğitimcisi öğretmenlerin tükenmişlik ve mesleki yetkinliklerinin incelenmesi. Mehmet Akif Ersoy Üniversitesi Sosyal Bilimler Enstitüsü Dergisi, 4, 38-53.

Çitemel, N. (2014). Çözüm odaklı kısa süreli grupla psikolojik danışmanın lise öğrencilerinin akran zorbalı̆̆ına etkisi. Yayımlanmamış doktora tezi. Sakarya Üniversitesi Eğitim Bilimleri Enstitüsü, Sakarya.

De Jong, P., \& Berg, I. K. (1998). Interviewing for solutions. Pacific Grove CA: Brooks/ Cole.

De Shazer, S. (1985). Keys to solution in brief therapy. New York: W.W. Norton\& Company Inc.

De Shazer, S., \& Berg I. K. (1997). 'What works?’ Remarks on research aspects of solution-focused brief therapy. Journal of Family Therapy, 19, 121-124. http://dx.doi.org/10.1111/1467-6427.00043

Doğan, S. (1999). Çözüm odaklı kısa süreli terapi: Kuramsal bir inceleme. Türk Psikolojik Danışma ve Rehberlik Dergisi, 2(12), 28-38.

Franklin, C., Moore, K., \& Hopson, L. (2008). Effectiveness of solution-focused brief therapy in a school setting. Children \& Schools, 30(1), 15-26. http://dx.doi.org/10.1093/cs/30.1.15

Freudenberger, H. J. (1974). Staff burn - out. Journal of social issues, 30(1), 159-165. http://dx.doi.org/10.1111/j.1540-4560.1974.tb00706.x

Gan, Y., Yang, M., Zhou, Y., \& Zhang, Y. (2007). The two-factor structure of future-oriented coping and its mediating role in student engagement.Personality and Individual Differences, 43(4), 851-863. http://dx.doi.org/10.1016/j.paid.2007.02.009

Gladding, S. T. (2013). Psikolojik danışma. (6. Baskı). (Çev. Ed. N. Voltan Acar; Çev. T. Sarı). Ankara: Nobel Akademik Yayıncılık.

Gündüz, B. (2005). ilköğretim Öğretmenlerinde Tükenmişlik. Mersin Üniversitesi Ĕ̌itim Fakültesi Dergisi, 1(1), $152-166$.

Gündüz, B., Çapri, B. \& Gökçakan, Z. (2012). Üniversite öğrencilerinin tükenmişlik düzeylerinin incelenmesi. Dicle Üniversitesi Ziya Gökalp Ĕ̈itim Fakültesi Dergisi, 19, 38-55.

Günüşen, N. P. \& Üstün, B. (2010). Türkiye'de ikinci basamak sağllk hizmetlerinde çalışan hemşire ve hekimlerde tükenmişlik: literatür incelemesi.Dokuz Eylül Üniversitesi Hemşirelik Yüksekokulu Elektronik Dergisi, 3(1), 40-51.

Hakanen, J. J., Bakker, A. B. \& Schaufeli, W. B. (2006). Burnout and work engagement among teachers. Journal of school psychology, 43(6), 495-513. http://dx.doi.org/10.1016/j.jsp.2005.11.001

Horn, J. E., Schaufeli, W. B., \& Enzmann, D. (1999). Teacher Burnout and Lack of Reciprocity. Journal of Applied Social Psychology, 29(1), 91-108. http://dx.doi.org/10.1111/j.1559-1816.1999.tb01376.x

İkiz, F. E. (2010). Psikolojik Danışmanların Tükenmişlik Düzeylerinin İncelenmesi. Ahi Evran Üniversitesi Eğitim Fakültesi Dergisi, 11(2), 25-43.

İlbay, A. B. (2014). Çözüm odaklı kısa süreli grupla psikolojik danışmanın üniversite öğrencilerinin tükenmişlik düzeyleri üzerindeki etkisi. Yayımlanmamış doktora tezi. Sakarya Üniversitesi Eğitim Bilimleri Enstitüsü, Sakarya.

Karahan, Ş., \& Balat, G. U. (2011). Özel eğitim okullarında çalışan eğitimcilerin öz-yeterlik algılarının ve tükenmişlik düzeylerinin incelenmesi. Pamukkale Üniversitesi Ĕ̆itim Fakültesi Dergisi, 29(29), 1-14.

Kim, M. Y., Lee, J. Y., \& Kim, J. (2009). Relationships among burnout, social support, and negative mood regulation expectancies of elementary school teachers in Korea. Asia Pacific Education Review, 10(4), 475-482. http://dx.doi.org/10.1007/s12564-009-9045-9

Kravits, K., McAllister-Black, R., Grant, M., \& Kirk, C. (2010). Self-care strategies for nurses: A psycho-educational intervention for stress reduction and the prevention of burnout. Applied Nursing Research, 23(3), 130-138. http://dx.doi.org/10.1016/j.apnr.2008.08.002

Küçüksüleymanoğlu, R. (2007). Eğitim fakültesi öğretim elemanlarının tükenmişlik düzeyleri. Eğitim Araştırmaları, 28, 
101-112.

Küçüksüleymanoğlu, R., \& Eğilmez, H. O. (2013). Müzik Öğretmeni Adaylarının Tükenmişlik Düzeyleri: Uludağ Üniversitesi Örneği. International Journal of Social Science, 6(3), 905-923.

Kutsal, D., \& Bilge, F. (2012). Lise Öğrencilerinin Tükenmişlik ve Sosyal Destek Düzeyleri A Study on the Burnout and Social Support Levels of High School Students. Education, 37(164), 283-297.

Lambie, G. W. (2006). Burnout prevention: A humanistic perspective and structured group supervision activity. The Journal of Humanistic Counseling, Education and Development, 45(1), 32-44. http://dx.doi.org/10.1002/j.2161-1939.2006.tb00003.x

Lethem, J. (2002). Brief solution focused therapy. Child and Adolescent Mental Health, 7(4), 189-192. http://dx.doi.org/10.1111/1475-3588.00033

Maslach, C., \& Goldberg, J. (1998). Prevention of burnout: New perspectives.Applied and preventive psychology, 7(1), 63-74. http://dx.doi.org/10.1016/S0962-1849(98)80022-X

Maslach, C., \& Jackson, S. E. (1981). The measurement of experienced burnout. Journal of Occupational Behaviour, 2 , 99-113. http://dx.doi.org/10.1002/job.4030020205

Maslach, C., \& Jackson, S. E. (1984). Burnout in organizational settings. Applied social psychology annual, 5, $133-153$.

Maslach, C., Schaufeli, W. B., \& Leiter, M. P. (2001). Job burnout. Annual review of psychology, 52(1), $397-422$. http://dx.doi.org/10.1146/annurev.psych.52.1.397

Meier, S. T., \& Schmeck, R. R. (1985). The burned-out college student: A descriptive profile. Journal of College Student Personnel. 26(1), 63-69.

Millicent, H. A., \& Joanne, S. (1999) Stress and Burnout in Rural and Urban Secondary School Teachers, The Journal of Educational Research, 92(5), 287-293. http://dx.doi.org/10.1080/00220679909597608

Murdock, N. L. (2012). Psikolojik danışma ve psikoterapi kuramları. (Çev. F. Akkoyun). Ankara: Nobel Akademik Yayıncilik.

Newsome, W. S. (2005). The impact of solution-focused brief therapy with at-risk junior high school students. Children \& Schools, 27(2), 83-90. http://dx.doi.org/10.1093/cs/27.2.83

Otacıŏlu, S. G. (2008). Müzik öğretmenlerinde tükenmişlik sendromu ve etkileyen faktörler. Inönü Üniversitesi Ĕgitim Fakültesi Dergisi, 9(15), 103-116.

Salmela-Aro, K., Savolainen, H., \& Holopainen, L. (2009). Depressive symptoms and school burnout during adolescence: Evidence from two cross-lagged longitudinal studies. Journal of Youth and Adolescence, 38(10), 1316-1327. http://dx.doi.org/10.1007/s10964-008-9334-3

Sayıl, I., Haran, S., Ölmez, Ş., \& Özgüven, H. D. (1997). Ankara Üniversitesi Hastanelerinde Çalışan Doktor Ve Hemşirelerin Tükenmişlik Düzeyleri.Kriz Dergisi, 5(2), 71-77. http://dx.doi.org/10.1501/0000867

Schaufeli, W. B., \& Maslach, C. (1993). Historical and conceptual development of burnout. Professional burnout: Recent developments in theory and research, Washington, DC: Taylor\&Francis.

Seçer, İ., \& Gençdoğan, B. (2012). Ortaöğretim öğrencilerinde okul tükenmişliğinin çeşitli değişkenlere göre incelenmesi. Turkish Journal of Education, 1(2), 1-13.

Sklare, G. B. (2013). Okul danışmanları için çözüm odaklı kısa süreli psikolojik danışma. (4. Baskı). ( Çev. D. M. Siyez ). Ankara: Pegem Akademi Yayıncılık.

Tuna, D. (2012). Çözüm odakl kısa süreli yaklaşıma dayalı öfke kontrolü eğitim programının lise öğrencilerinin öfke kontrolü ve iletişim becerileri düzeylerine etkisi. Yayımlanmamış yüksek lisans tezi. Dokuz Eylül Üniversitesi Eğitim Bilimler Enstitüsü, İzmir.

Ünal, S., Karlıdağ, R., \& Yoloğlu, S. (2001). Hekimlerde tükenmişlik ve iş doyumu düzeylerinin yaşam doyumu düzeyleri ile ilişkisi. Klinik Psikiyatri, 4(2), 113-118.

Vahey, D. C., Aiken, L. H., Sloane, D. M., Clarke, S. P., \& Vargas, D. (2004). Nurse burnout and patient satisfaction. Medical Care, 42(2), 1157-1166. http://dx.doi.org/10.1097/01.mlr.0000109126.50398.5a

Vallaire, L.T., Hicks, J., \& Growe, R. (2011). Solution-focused brief therapy: An interventional approach to improving negative student behaviors. Journal of Instructional Psychology, 38(4), 224-234.

Yang, H. J., \& Farn, C. K. (2005). An investigation the factors affecting MIS student burnout in technical-vocational college. Computers in Human Behavior, 21(6), 917-932. http://dx.doi.org/10.1016/j.chb.2004.03.001

\section{$(\mathrm{Cc}) \mathrm{Br}$}

This work is licensed under a Creative Commons Attribution 3.0 License. 